\title{
MODEL DISTRIBUSI DIAMETER LIMA JENIS POHON PADA HUTAN TROPIKA BASAH DI KABUPATEN MAMUJU, SULAWESI BARAT
}

\author{
Diameter Distribution Model for Five Tree Species on Tropical Rain Forest in Mamuju District, \\ West Sulawesi \\ Beta Putranto
}

\begin{abstract}
The objective of this research is to establish the most suitable tree diameter distribution model for five tree species on tropical rain forest in Mamuju District. This research was conducted on two locations. The 50 square plots were sampled systematically for seedling, sapling, pole and tree measurements of bintangur, jambu-jambu, lada-lada, matoa and nyatoh species. The distance among plots was $50 \mathrm{~m}$. Variables to be measured were stem number of seedlings to trees and tree diameter at breast height $(1,3 \mathrm{~m})$ of saplings to trees. About $70 \%$ of the data were used to establish the best model, the rest of $30 \%$ were used to validate the model. Models to be analyzed were fourth-order semi-logarithmic transformed polynomial function, Weibull density function and monotonic decreasing Weibull function. The results show that the five tree species have a similar diameter distribution pattern. The shape of this distribution is the typical of unevenaged stand distribution on natural forest, namely reversed $\mathrm{J}$ shape. The most suitable model for five species is second-order semi-logarithmic transformed polynomial function.
\end{abstract}

Key words: model, diameter distribution, natural forest, uneven-aged stand.

\section{PENDAHULUAN}

Distribusi diameter pohon merupakan salah satu faktor penting dalam manajemen hutan karena sering digunakan dalam menggambarkan struktur hutan, menentukan stabilitas dan keragaman hayati suatu hutan, dan mensimulasi model hasil dan pertumbuhan. Berbagai fungsi kepekatan peluang telah digunakan di bidang kehutanan untuk memodel distribusi diameter pohon. Beberapa dari fungsi kepekatan peluang yang menggambarkan distribusi diameter tegakan seumur menurut Mingliang and Keith (2007), Maltamo et al. (2007), dan Bruce et al. (2008) antara lain adalah distribusi normal, log-normal, Gamma, Beta, Weibull, logistik, logit logistik dan Johnson's SB.

Dibandingkan dengan kajian-kajian pada tegakan seumur, penelitian yang berhubungan dengan distribusi diameter pada hutan tidak seumur relatif sedikit. De Liocourt (1898) dalam Maria et al. (2008) menemukan bahwa distribusi diameter dari hutan fir (Abies spp.) di Perancis mempunyai pola bentuk $J$ terbalik. Pada tahun 1952, Meyer menemukan pola distribusi diameter yang sama di wilayah timur laut Amerika Serikat dan mendiskripsikannya dengan menggunakan suatu konstanta quosien q, yaitu rasio antara jumlah pohon pada suatu kelas diameter tertentu dengan kelas diameter berikutnya. Pola ini sering disebut bentuk distribusi eksponensial negatif.

Selama ini penelitian-penelitian tentang pendugaan potensi hutan khususnya yang berhubungan dengan distribusi diameter lebih banyak diarahkan pada hutan tanaman, sedikit sekali yang berhubungan dengan hutan alam terutama hutan tropika basah di Sulawesi. Untuk menghindari kesalahan-kesalahan dalam pendugaan potensi hutan, terutama yang berhubungan dengan distribusi diameter dari tingkat semai sampai dengan pohon, khususnya di Kabupaten Mamuju Sulawesi Barat, diperlukan suatu model yang sesuai. Pendugaan model distribusi diameter yang akurat akan sangat bermanfaat dalam kegiatan perencanaan hutan untuk menjamin terwujudnya pengelolaan hutan lestari.

\section{BAHAN DAN METODE}

\section{Tempat Penelitian}

Tempat penelitian adalah hutan tropika basah pada dua lokasi di Kabupaten Mamuju Sulawesi 
Barat. Lokasi I terletak di Kecamatan Bonehau, yang berada pada areal IUPHHK PT. Inhutani I Unit Manajemen Hutan Mamuju, sedang lokasi II terletak di Kecamatan Topoyo, yang berada pada areal IUPHHK PT. Zedsko Permai.

\section{Alat dan Bahan}

Alat-alat yang digunakan adalah roll meter, pita diameter, tali plastik, parang, kuas, seperangkat alat keamanan kerja, buku ukur dan alat tulis. Bahan yang dibutuhkan adalah cat.

\section{Penentuan Petak Ukur}

Petak ukur untuk pengukuran permudaan dan pohon berbentuk bujur sangkar yang ditetapkan sebanyak 50 petak ukur pada masing-masing lokasi. Penentuan petak ukur dilakukan dengan menggunakan teknik penarikan sampel secara sistematik dengan jarak sama antar petak ukur (Equidistant square plots systematic sampling). Jarak antar petak ukur $50 \mathrm{~m}$. Ukuran petak ukur masing-masing adalah $20 \mathrm{~m} \times 20 \mathrm{~m}$ untuk pohon, $10 \mathrm{~m} \times 10 \mathrm{~m}$ untuk tiang, $5 \mathrm{~m} \times 5 \mathrm{~m}$ untuk pancang dan $2 \mathrm{~m} \times 2 \mathrm{~m}$ untuk semai. Setiap pancang sampai pohon dalam petak ukur diukur diameter setinggi dada dan dicatat jenisnya. Untuk semai hanya dihitung jumlah batang setiap jenis.

\section{Analisis Data}

Tahapan yang dilakukan dalam menganalisis distribusi diameter adalah sebagai berikut:

a. Menghitung rata-rata jumlah batang per ha berdasarkan kelas diameter setinggi dada dengan lebar kelas diameter $5 \mathrm{~cm}$ menurut jenis. Permudaan tingkat semai tidak dimasukkan ke dalam kelas diameter karena dianggap diameter setinggi dada kurang dari $1 \mathrm{~cm}$.

b. Distribusi frekuensi kelas diameter dikonversi menjadi distribusi frekuensi relatif (\%).

c. Pola distribusi frekuensi untuk setiap jenis dalam lokasi yang sama diuji dengan uji kesesuaian distribusi Kolmogorov-Smirnov Z (K-S Z).

d. Berdasarkan hasil pengamatan secara grafis dan uji kesesuaian distribusi K-S Z, selanjutnya dianalisis model distribusi diameter yang paling sesuai.

Sebesar $70 \%$ dari data yang diperoleh digunakan di dalam pemilihan model sedang sisanya digunakan untuk validasi model. Apabila data yang digunakan dalam validasi model sedikit, maka data yang digunakan dalam validasi adalah seluruh data yang tersedia.

Model yang dianalisis adalah fungsi polinomial transformasi semi logaritma ordo 4 (MD1), fungsi kepekatan Weibull dengan dua parameter (MD2) dan fungsi monoton turun Weibull dengan tiga parameter (MD3) sebagai berikut :

MD1 : $\quad \operatorname{Ln} Y_{i}=\beta_{0}+\beta_{1} D_{i}+\beta_{2} D_{i}^{2}+\beta_{3} D_{i}^{3}+$ $\beta_{4} D_{i}^{4}+\varepsilon_{i}$

MD2 : $Y_{i}=\frac{\gamma}{\beta}\left(\frac{D_{i}}{\beta}\right)^{\gamma-1} \exp \left\{-\left(\frac{D_{i}}{\beta}\right)^{\gamma}\right\}+\varepsilon_{i}$

MD3 : $Y_{i}=\alpha \exp \left\{-\left(\frac{D_{i}}{\beta}\right)^{\gamma}\right\}+\varepsilon_{i}$

di mana:

$Y_{i}$ adalah frekuensi relatif kelas ke $\mathrm{i}$

$D_{i}$ adalah nilai tengah kelas diameter ke $\mathrm{i}$

$\beta_{0}, \beta_{1}, \beta_{3}, \beta_{4}, \alpha, \beta$ dan $\gamma$ adalah parameter model

$\varepsilon_{i}$ adalah komponen galat dari model

Penentuan calon model terbaik menggunakan kriteria Koefisien Determinasi $\left(R^{2}\right)$ untuk model linier atau pseudo-coefficient of multiple determination untuk model non linier, yang dihitung dengan menggunakan rumus :

$$
R^{2}=1-\frac{\sum_{i=1}^{n}\left(Y_{i}-\hat{Y}_{i}\right)^{2}}{\sum_{i=1}^{n}\left(Y_{i}-\bar{Y}_{i}\right)^{2}}
$$

Model terpilih selanjutnya divalidasi dengan menggunakan kriteria bias rata-rata, mean squared error prediction (MSEP) dan Indeks galat (EI). Rumus bias rata-rata dan MSEP (Rawlings, 1988) serta El (Reynolds et al., 1988) adalah sebagai berikut:

$$
\begin{aligned}
& \text { Bias }=\frac{\sum_{i=1}^{n}\left(Y_{i}-\hat{Y}_{i}\right)}{n} \\
& M S E P=\frac{\sum_{i=1}^{n}\left(Y_{i}-\hat{Y}_{i}\right)^{2}}{n} \\
& E I=\sum_{i=1}^{n}\left|Y_{i}-\hat{Y}_{i}\right|
\end{aligned}
$$

di mana:

$Y_{i}$ adalah nilai pengamatan ke $\mathrm{i}$

$\hat{Y}_{i}$ adalah nilai dugaan ke $\mathrm{i}$

$\mathrm{n}$ adalah banyaknya pengamatan 


\section{HASIL DAN PEMBAHASAN}

\section{Distribusi Jumlah Batang Berdasarkan Jenis}

Komposisi jenis yang menyusun hutan pada kedua lokasi relatif sama meskipun ada beberapa jenis yang ditemukan di lokasi I tidak ditemukan pada lokasi II dan sebaliknya. Pada lokasi I untuk tingkat semai ditemukan 26 jenis, pancang 28 jenis, tiang 32 jenis, dan pohon 32 jenis. Pada lokasi II untuk tingkat semai ditemukan 25 jenis, pancang 28 jenis, tiang 32 jenis, dan pohon 39 jenis. Jumlah permudaan dan pohon seluruh jenis per petak ukur yang ditemukan di lokasi I lebih sedikit dibandingkan dengan yang ditemukan di lokasi II. Jenis yang secara khusus dianalisis sebanyak lima jenis, yaitu bintangur (Calophyllum sp., famili Guttiferae), jambu-jambu (Kjellbergiodendron sp., famili Myrtaceae), ladalada (Endiandra sp., famili Lauraceae), matoa (Pometia sp., famili Sapindaceae) dan nyatoh (Palaquium sp., famili Sapotaceae). Pemilihan jenis tersebut didasarkan pada pertimbangan bahwa keberadaan ke lima jenis tersebut ditemukan pada kedua lokasi dan cukup dominan pada salah satu atau kedua lokasi sehingga potensial untuk dikembangkan.

Secara umum struktur tegakan pada hutan alam yang tidak seumur seperti kondisi hutan pada lokasi penelitian terdiri atas berbagai tingkat pertumbuhan mulai dari tingkat semai sampai dengan tingkat pohon. Semakin tinggi tingkat pertumbuhan (dari semai sampai pohon), semakin sedikit frekuensi jumlah batang per ha Distribusi jumlah batang per ha berdasarkan jenis disajikan pada Tabel 1. dan Tabel 2.

Tabel 1. dan Tabel 2. menunjukkan bahwa jumlah semai pada kedua lokasi cukup banyak dan semakin tinggi tingkat pertumbuhan (dari semai sampai pohon), semakin sedikit frekuensi jumlah batang per ha. Distribusi yang seperti ini pada hutan alam merupakan penciri dari jenisjenis toleran atau semi toleran yaitu jenis-jenis yang semainya dapat tumbuh dengan baik di bawah naungan (Whitmore and Burnham, 1984). Pada kondisi yang cocok jumlah semai akan cukup banyak. Sebagian besar dari semai ini tidak mampu bertahan hidup dan akhirnya akan mati karena berbagai sebab, antara lain persaingan dalam memperoleh ruang tumbuh, serangan

Table 1. Distribution of stem number per hectare at site I

\begin{tabular}{|c|c|c|c|c|c|c|c|c|c|}
\hline \multirow[b]{2}{*}{ No. } & \multirow[b]{2}{*}{ Species } & \multicolumn{2}{|c|}{ Seedling } & \multicolumn{2}{|c|}{ Sapling } & \multicolumn{2}{|c|}{ Pole } & \multicolumn{2}{|c|}{ Tree } \\
\hline & & $\begin{array}{l}\text { stem } \\
\text { per ha }\end{array}$ & $\%$ & $\begin{array}{l}\text { stem } \\
\text { per ha }\end{array}$ & $\%$ & $\begin{array}{l}\text { stem } \\
\text { per ha }\end{array}$ & $\%$ & $\begin{array}{l}\text { stem } \\
\text { per ha }\end{array}$ & $\%$ \\
\hline 1. & Bintangur & 1950 & 23,6 & 56 & 6,8 & 10 & 3,0 & 3 & 2,5 \\
\hline 2. & Jambu-jambu & 300 & 3,6 & 24 & 2,9 & 10 & 3,0 & 7 & 5,8 \\
\hline 3. & Lada-lada & 900 & 10,9 & 56 & 6,8 & 10 & 3,0 & 2 & 1,6 \\
\hline 4. & Matoa & 650 & 7,9 & 40 & 4,9 & 14 & 4,2 & 4 & 3,3 \\
\hline 5. & Nyatoh & 1250 & 15,2 & 56 & 6,8 & 40 & 12,0 & 10 & 8,3 \\
\hline Gab & Lima Jenis & 5050 & 61,2 & 232 & 28,2 & 84 & 25,2 & 26 & 21,5 \\
\hline Jenis & Lainnya & 3200 & 38,8 & 592 & 71,8 & 250 & 74,9 & 95 & 78,5 \\
\hline & Total & 8250 & 100,0 & 824 & 100,0 & 334 & 100,0 & 121 & 100,0 \\
\hline
\end{tabular}

Table 2. Distribution of stem number per hectare at site II

\begin{tabular}{|c|c|c|c|c|c|c|c|c|c|}
\hline \multirow[b]{2}{*}{ No. } & \multirow[b]{2}{*}{ Species } & \multicolumn{2}{|c|}{ Seedling } & \multicolumn{2}{|c|}{ Sapling } & \multicolumn{2}{|c|}{ Pole } & \multicolumn{2}{|c|}{ Tree } \\
\hline & & $\begin{array}{c}\text { stem } \\
\text { per ha }\end{array}$ & $\%$ & $\begin{array}{l}\text { stem } \\
\text { per ha }\end{array}$ & $\%$ & $\begin{array}{l}\text { stem } \\
\text { per ha }\end{array}$ & $\%$ & $\begin{array}{l}\text { stem } \\
\text { per ha }\end{array}$ & $\%$ \\
\hline 1. & Bintangur & 1050 & 5,0 & 40 & 2,0 & 10 & 2,5 & 4 & 2,1 \\
\hline 2. & Jambu-jambu & 3950 & 19,7 & 200 & 9,9 & 32 & 8,2 & 14 & 7,3 \\
\hline 3. & Lada-lada & 1000 & 4,7 & 96 & 4,8 & 30 & 7,6 & 13 & 6,8 \\
\hline 4. & Matoa & 150 & 0,7 & 40 & 2,0 & 12 & 3,1 & 10 & 5,3 \\
\hline & Nyatoh & 400 & 1,9 & 64 & 3,1 & 18 & 4,6 & 10 & 5,3 \\
\hline Gab & Lima Jenis & 6550 & 31,0 & 440 & 21,8 & 102 & 26,0 & 51 & 26,8 \\
\hline Jenis & Lainnya & 14600 & 69,0 & 1576 & 78,2 & 290 & 74,0 & 139 & 73,2 \\
\hline & Total & 21150 & 100,0 & 2016 & 100,0 & 392 & 100,0 & 190 & 100,0 \\
\hline
\end{tabular}


hama dan penyakit, dimakan atau terinjak-injak oleh binatang. Hanya sebagian kecil yang tumbuh pancang. Jumlahnya akan semakin berkurang sejalan dengan pertumbuhan sampai mencapai tingkat pohon. Semakin tinggi tingkat permudaan ada kecenderungan semakin tinggi pula kemampuan menghadapi persaingan.

Setiap jenis mempunyai kepekaan terhadap cahaya yang berbeda-beda. Jumlah individu tingkat permudaan dan pohon pada lokasi I lebih sedikit (kurang rapat) dibandingkan dengan lokasi II. Secara keseluruhan terdapat perbedaan kerapatan tingkat permudaan yang mencolok, khususnya tingkat semai dan pancang antara lokasi I dan lokasi II. Jumlah total semai dan pancang pada lokasi II sekitar 2,5 kali lipat dari yang ada pada lokasi I dengan total jumlah semai sekitar sepuluh kali lipat jumlah pancangnya, sementara tingkat tiang dan pohon perbedaannya sekitar $28 \%$. Semai yang memerlukan naungan penuh, jumlahnya akan berkurang pada tegakan yang kerapatannya lebih kecil. Jenis-jenis seperti bintangur, matoa dan nyatoh mempunyai semai lebih banyak pada lokasi I dibandingkan lokasi II. Hal ini mengindikasikan bahwa jenis tersebut tidak terlalu tahan terhadap naungan dibandingkan dengan jenis jambu-jambu meskipun semuanya

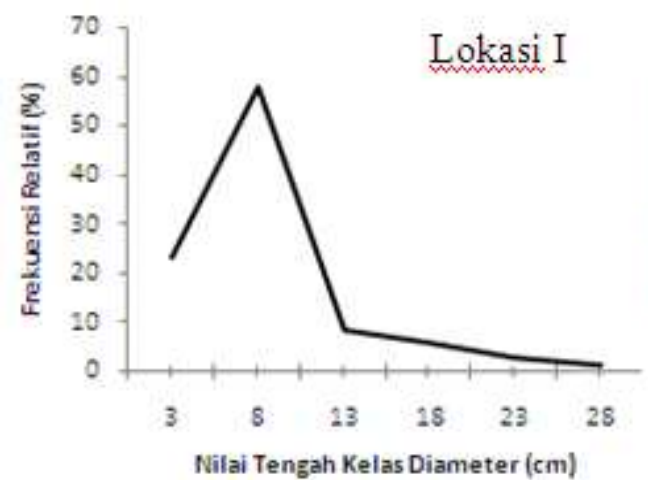

Figure 1. Diameter distribusi for bintangur

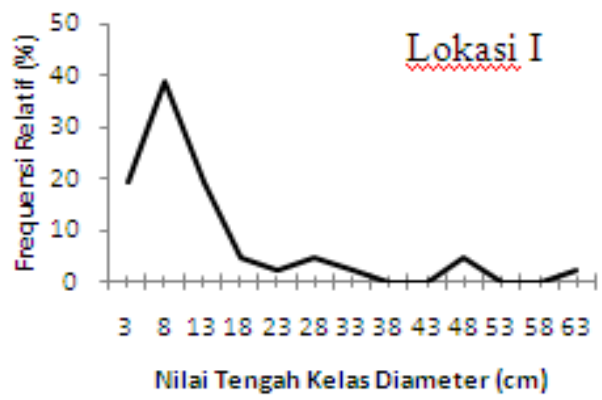

Figure 2. Diameter distribution for jambu-jambu termasuk jenis semi toleran. Jenis lada-lada relatif dapat beradaptasi pada kerapatan yang berbeda.

\section{Distribusi Diameter}

Distribusi diameter (tidak termasuk semai) pada luasan yang kecil (per plot) mempunyai bentuk yang bervariasi dan sangat tidak teratur. Pada tingkat luasan yang lebih besar ketidak teraturan distribusi tersebut akan menjadi lebih teratur dan membentuk suatu pola tertentu. Pola distribusi diameter setiap jenis mempunyai kemiripan dengan distribusi gabungan lima jenis dari setiap lokasi, yaitu unimodal untuk lokasi I dan J terbalik untuk lokasi II (Gambar 1-6). Hal ini sesuai dengan hasil uji kesesuaian distribusi Kolmogorov-Smirnov $Z$ yang menyatakan bahwa distribusi diameter setiap jenis pada lokasi yang sama mempunyai kemiripan pola distribusi, begitu juga antar jenis dengan gabungan lima jenis kecuali untuk jenis lada-lada pada lokasi I, sedang distribusi diameter gabungan lima jenis pada lokasi I dan lokasi II mempunyai pola distribusi yang berbeda. Dengan demikian, analisis distribusi diameter dilakukan untuk masing-masing lokasi.
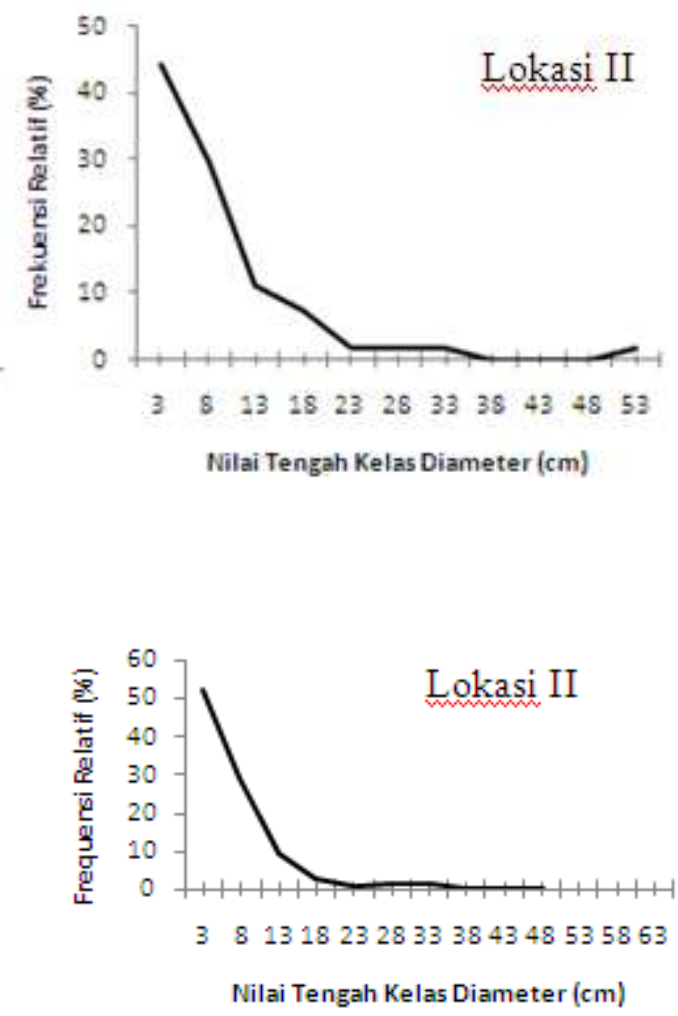

Nilai Tengah Kelas Diameter $(\mathrm{cm})$ 

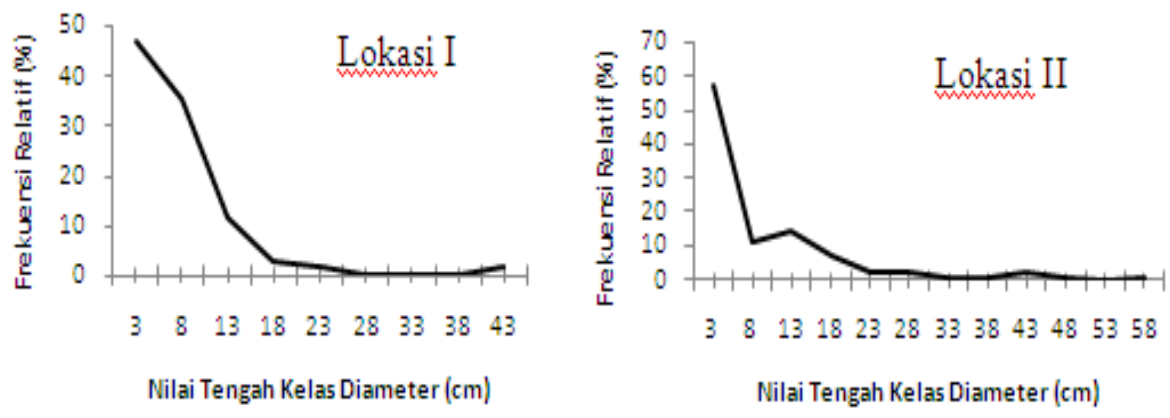

Figure 3. Diameter distribusi for lada-lada
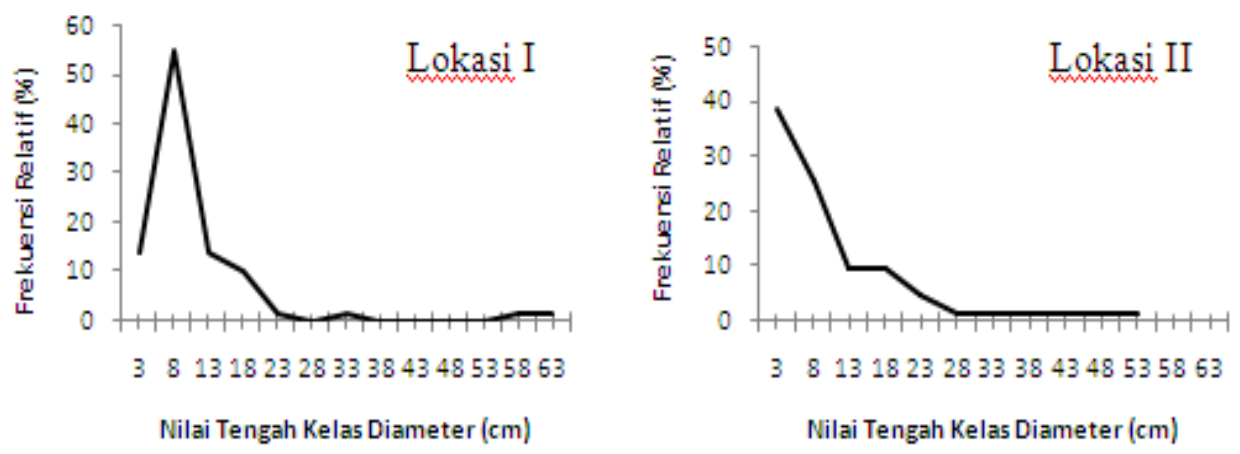

Figure 4. Diameter distribution for matoa
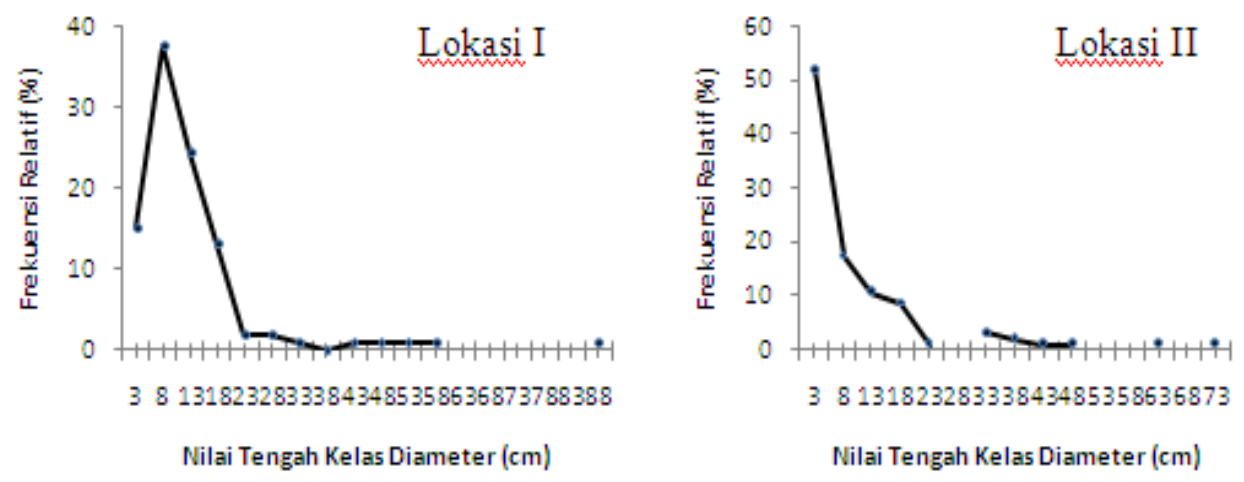

Figure 5. Diameter distribution for nyatoh
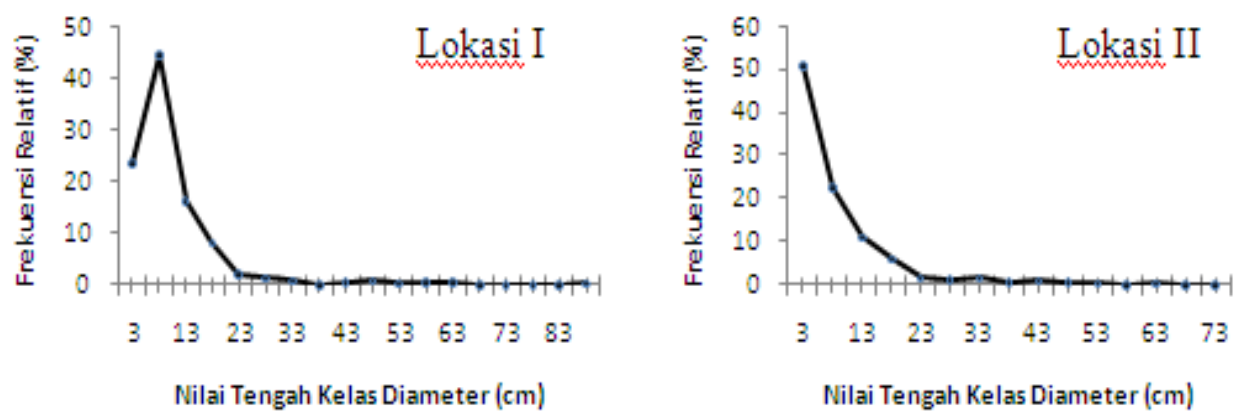

Figure 6. Diameter distribution for mix five species 
Tabel 3. The estimate of diameter distribution model

\begin{tabular}{|c|c|c|c|c|}
\hline No. & Sites & Model & Estimated Model & $\mathrm{R}^{2}$ \\
\hline 1. & I & MD1 & $\widehat{\operatorname{LnY}}=4,1810-0,1494 \mathrm{D}+0,0010 \mathrm{D}^{2}$ & 0,887 \\
\hline 2. & I & MD2 & $\hat{Y}=108,63\left(\frac{D}{9,42}\right)^{1,412} \exp \left[-\left(\frac{D}{9,42}\right)^{2,412}\right]$ & 0,951 \\
\hline 3. & 1 & MD3 & $\hat{Y}=30,577 \exp \left[-\left(\frac{D}{17,237}\right)^{4,104}\right]$ & 0,782 \\
\hline 4. & \| & MD1 & $\widehat{\operatorname{LnY}}=4,4006-0,1733 \mathrm{D}+0,0013 \mathrm{D}^{2}$ & 0,945 \\
\hline 5. & $\|$ & MD2 & $\hat{Y}=79,93\left(\frac{D}{6,78}\right)^{0,022} \exp \left[-\left(\frac{D}{6,78}\right)^{1,022}\right]$ & 0,999 \\
\hline 6. & II & MD3 & $\hat{Y}=76,837 \exp \left[-\left(\frac{D}{7,039}\right)^{1,037}\right]$ & 0,999 \\
\hline
\end{tabular}

Analisis regresi terhadap model MD1 dengan menggunakan metode stepwise untuk memilih persamaan regresi terbaik menghasilkan persamaan regresi ordo dua. Semua model distribusi diameter yang dianalisis menghasilkan nilai $R^{2}$ yang cukup besar, yaitu berkisar antara $78,2 \%$ sampai dengan $99,9 \%$ (Tabel 3). Hal ini menunjukkan bahwa ketiga model yang dianalisis layak untuk dijadikan sebagai penduga model bagi distribusi diameter. Penduga model MD2 pada lokasi I mempunyai nilai $\mathrm{R}^{2}$ terbesar, sedang pada lokasi II yang mempunyai nilai $\mathrm{R}^{2}$ terbesar adalah MD2 dan MD3. Meskipun demikian, untuk mengetahui apakah model tersebut cukup beralasan untuk digunakan sebagi penduga model distribusi diameter, perlu dilakukan validasi model dengan data independen. Hasil validasi model disajikan pada Tabel 4.

(a) Lokasi I

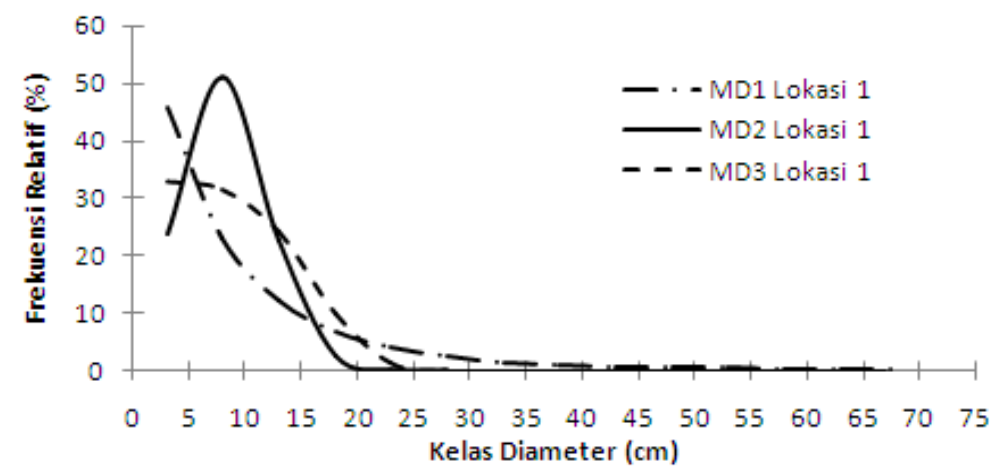

(b) Lokasi II

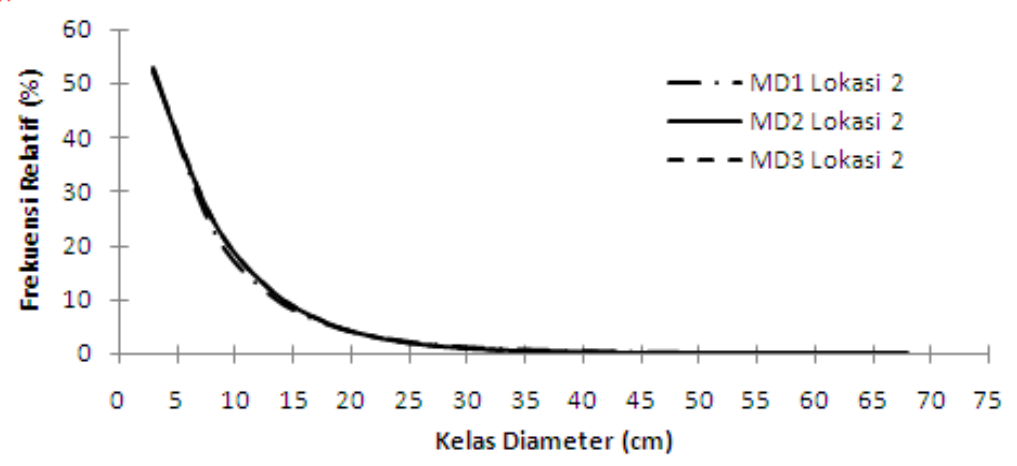

Figure 7. Graph of the estimate of diameter distribution model 
Table 4. Bias, MSEP and El of the three estimate of diameter distribution model for mix five species

\begin{tabular}{cccccccccc}
\multirow{2}{*}{ No. } & \multirow{2}{*}{ Models } & \multicolumn{2}{c}{ Bias } & \multicolumn{2}{c}{ MSEP } & \multicolumn{2}{c}{ El } & Score & \multirow{2}{*}{ Ranks } \\
\cline { 2 - 7 } & & value & Skor & value & Skor & value & Skor & Total & \\
\hline & Lokasi I & & & & & & & & \\
\hline 1. & MD1 & 0,0657 & 1 & 51,0392 & 1 & 50,58 & 1 & 3 & 3 \\
2. & MD2 & 0,0043 & 3 & 11,1492 & 3 & 28,60 & 3 & 9 & 1 \\
3. & MD3 & 0,0050 & 2 & 19,7013 & 2 & 34,79 & 2 & 6 & 2 \\
\hline & Lokasi II & & & & & & & & \\
\hline 1. & MD1 & 0,0164 & 1 & 2,4175 & 3 & 14,15 & 3 & 7 & 1 \\
2. & MD2 & 0,0057 & 3 & 4,2570 & 1 & 18,70 & 1 & 5 & 3 \\
3. & MD3 & 0,0071 & 2 & 4,2286 & 2 & 18,64 & 2 & 6 & 2 \\
\hline
\end{tabular}

Model MD2 pada lokasi I merupakan penduga model yang mempunyai validitas tinggi. Terdapat kesesuaian antara penduga model dan validasi model MD2 pada lokasi I. Distribusi diameter yang berbentuk unimodal seperti yang ditunjukkan oleh MD2 mengindikasikan adanya gangguan pada awal pertumbuhan, di mana pada kelas diameter pertama $(1-5 \mathrm{~cm})$, frekuensi relatifnya lebih kecil dibandingkan kelas diameter kedua $(6-10 \mathrm{~cm})$. Untuk menjamin keberlangsungan pertumbuhan, diperlukan upaya untuk meningkatkan jumlah permudaan yang mempunyai diameter kecil (1-5 $\mathrm{cm}$ ) sehingga distribusi diameternya mempunyai bentuk $\mathrm{J}$ terbalik. Nilai penduga frekuensi relatif MD2 dan MD3 hanya sampai pada kelas diameter ke enam $(26-30 \mathrm{~cm})$. Kelas diameter di atas kelas diameter tersebut mempunyai frekuensi relatif yang besarnya mendekati $0 \%$. Hal ini tidak sesuai dengan hasil yang ditunjukkan oleh data, di mana masih banyak ditemukan pohon dengan diameter di atas $30 \mathrm{~cm}$. Dilihat dari grafik ketiga model, hanya MD1 yang mempunyai bentuk $\mathrm{J}$ terbalik (Gambar 7(a).). Dengan memperhatikan nilai $\mathrm{R}^{2}$ dari MD1 pada lokasi I yang cukup tinggi, maka masih cukup beralasan untuk menggunakan MD1 sebagai penduga model distribusi diameter.

Pada lokasi II, model yang mempunyai validitas tinggi adalah MD1. Terdapat perbedaan peringkat antara penduga model dengan validasi model. Gambar 7(b) memperlihatkan bahwa ketiga penduga model menghasilkan grafik yang berimpit. Hal ini menunjukkan bahwa ketiganya merupakan penduga model yang sama baiknya dan sangat sesuai untuk menduga distribusi diameter gabungan lima jenis. Dengan demikian, cukup beralasan jika MD1 digunakan sebagai penduga model distribusi diameter, baik pada lokasi I maupun lokasi II.

Persamaan distribusi diameter gabungan lima jenis berdasarkan model MD1 pada kedua lokasi mempunyai pola relatif sama (Gambar 8). Hasil uji kesamaan model pada kedua lokasi menyatakan bahwa penduga persamaan distribusi diameter model MD1 untuk kedua lokasi relatif sama (berbeda tidak nyata) sehingga cukup beralasan untuk menggabungkan data dari kedua lokasi

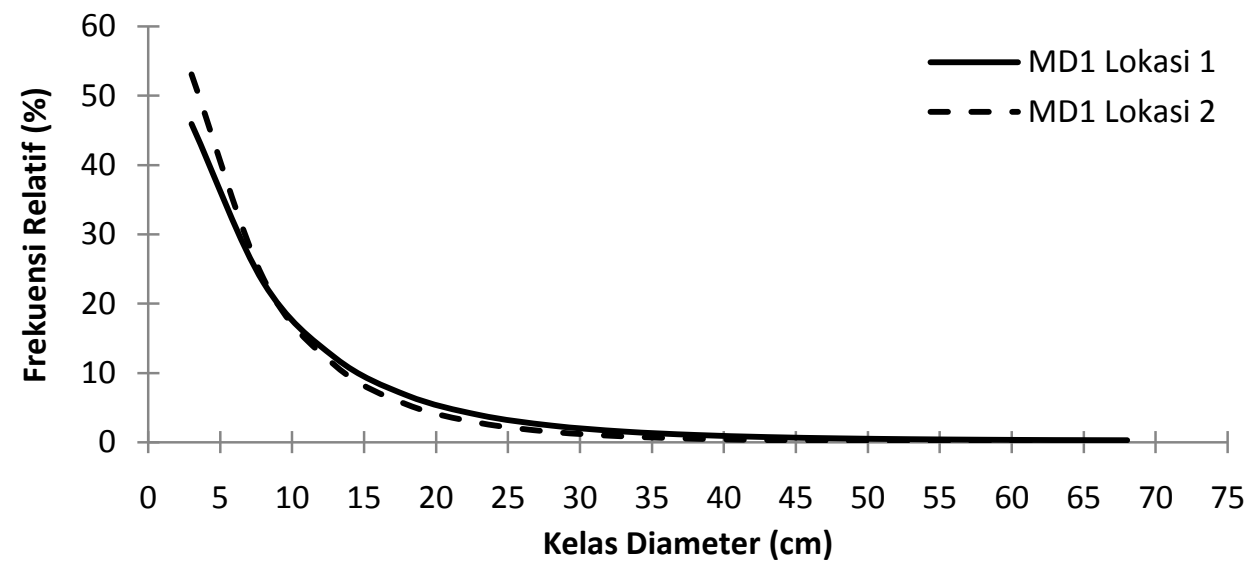

Figure 8. Graph of diameter distribution based on the estimate of second-order semi-logarithmic (MD1) 


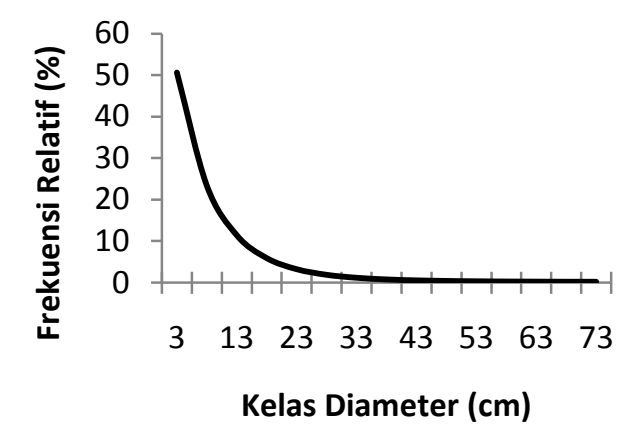

(a). Frekuensi relatif

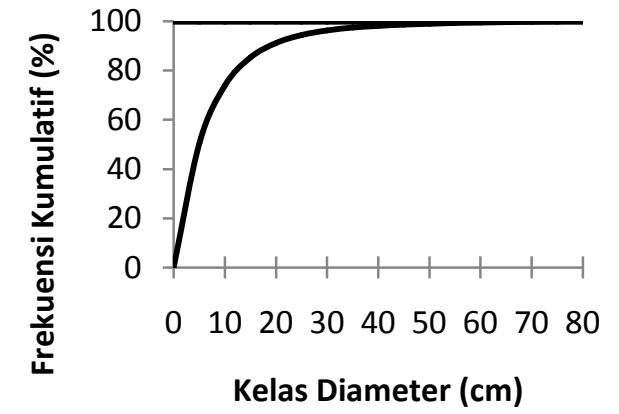

(b) Frekuensi kumulatif

Figure 4. Graphs of MD1 model of diameter distribution for mix five species

menjadi satu. Penduga persamaan regresi model MD1 adalah sebagai berikut :

$$
\widehat{\operatorname{Ln} Y}=4,4137-0,1669 D+0,0011 D^{2}
$$
dengan $R^{2}=0,928$.

Distribusi diameter yang dihasilkan berbentuk konkaf dengan frekuensi relatif terendah terjadi pada kelas $75-80 \mathrm{~cm}$. Hal ini menunjukkan bahwa di lokasi I maupun II sudah mulai jarang ditemui pohon dengan diameter $75-80 \mathrm{~cm}$. Untuk selanjutnya distribusi jumlah pohon dengan diameter di atas $80 \mathrm{~cm}$ dianggap mendekati nol. Grafik pada Gambar 4 menunjukkan bahwa distribusi frekuensi relatif gabungan lima jenis mempunyai bentuk kurva $\mathrm{J}$ terbalik. Pada kelas diameter kecil frekuensi relatif menurun secara tajam sampai dengan tingkat tiang yang berada pada kelas diameter $15-20 \mathrm{~cm}$, selanjutnya menjadi semakin datar pada tingkat pohon, yaitu pada kelas diameter di atas $20 \mathrm{~cm}$. Pada kelas diameter di atas $50 \mathrm{~cm}$ frekuensi relatif hampir sama, dengan nilai mendekati nol.

Mathieu et al. (2006), Maltamo et al. (2007), Bruce et al. (2008), Maria et al. (2008), Thomas and Emily (2008) menyatakan bahwa distribusi diameter pohon merupakan faktor yang penting dalam manajemen hutan. Implikasi dari distribusi diameter dalam manajemen hutan antara lain untuk menggambarkan struktur tegakan serta mensimulasi model hasil dan pertumbuhan untuk menetapkan alternatif pemanenan. Pada hutan alam tidak seumur distribusi diameter merupakan refleksi dari pertumbuhan meskipun umur dari pohon itu sendiri belum diketahui. Informasi penting lainnya untuk menggambarkan dinamika struktur tegakan selain distribusi diameter adalah riap dan tingkat kematian (mortalitas) pada setiap kelas diameter. Kedua informasi tersebut pada pengelolaan hutan alam dapat diperoleh melalui pengukuran secara periodik pada petak ukur permanen. Semakin panjang periode pengukuran semakin akurat informasi tentang riap dan mortalitas sehingga semakin akurat juga prediksi distribusi diameter pada waktu yang akan datang.

Meskipun distribusi diameter relatif sama tetapi secara absolut distribusi diameter dari setiap jenis dapat berbeda tergantung pada jumlah individu per satuan luas dari jenis tersebut. Dengan mengetahui distribusi absolutnya dapat diketahui potensi permudaan dan perilaku (behavior) permudaan dalam merespon faktor-faktor yang mempengaruhi pertumbuhannya, baik faktor biotik maupun abiotik sehingga dapat diambil tindakantindakan silvikultur yang tepat yang berhubungan dengan penanganan permudaan, khususnya untuk tingkat semai dan pancang.

Selain itu, berdasarkan informasi yang dikandung oleh distribusi diameter dapat diduga distribusi volume tegakan berdasarkan kelas diameter karena volume sangat berhubungan erat dengan diameter. Berdasarkan dinamika struktur tegakan, potensi permudaan dan tindakantindakan yang tepat terhadap permudaan serta distribusi potensi volume pada gilirannya dapat ditentukan sistem silvikultur yang paling tepat yang dapat menjamin kelestarian hutan.

\section{KESIMPULAN DAN SARAN}

\section{Kesimpulan}

Distribusi frekuensi relatif diameter gabungan lima jenis mempunyai bentuk $\mathrm{J}$ terbalik dengan penduga persamaan distribusi yang sama. Penduga persamaan hubungan antara frequensi 
relatif dengan kelas diameter yang paling sesuai adalah model polinomial transformasi semi logaritma ordo dua. Meskipun distribusi frequensi relatif diameter pada kedua lokasi sama, tetapi kerapatan permudaan dan pohon pada lokasi I lebih kecil dibandingkan dengan lokasi II.

\section{Saran}

Untuk meningkatkan jumlah semai sampai dengan pohon dan menjamin keberlangsungan pertumbuhannya, khususnya pada lokasi I, diperlukan upaya-upaya pengayaan dan pemeliharaan baik horizontal maupun vertikal yang sungguh-sungguh untuk memberikan pertumbuhan dan ruang hidup yang lebih baik, terutama tingkat semai yang sangat peka terhadap persaingan.

\section{DAFTAR PUSTAKA}

Bruce, E. B., W. Mingliang and Z. Dehai. 2008. Problems of Scaling Plantation Plot Diameter Distributions to Stand Level. Forest Science 54,349 .

Maltamo, M., A. Suvanto., and P. Packalén. 2007. Comparison of basal area and stem frequency diameter distribution modelling using airborne laser scanner data and

Diterima : 25 Oktober 2009

\section{Beta Putranto}

Lab. Keteknikan dan Diversifikasi Produk Hasil Hutan

Fakultas Kehutanan Universitas Hasanuddin

Jl. Perintis Kemerdekaan Km. 10 Tamalanrea, Makassar 90245 calibration estimation. Forest Ecology and Management 247, 26-34.

Maria, K. J., M. N. Linda, and R. W. Christopher. 2008. Spatial Scale and Stand Structure in Northern Hardwood Forests: Implications for Quantifying Diameter Distributions. Forest Science 54, 497.

Mathieu, F., U. Chhun-Huor, A. Louis, and B. Jean. 2006. Calibrating a Generalized Diameter Distribution Model with Mixed Effects. Forest Science 52, 650.

Mingliang, W., and R, Keith. 2007. Bivariate Distribution Modeling with Tree Diameter and Height Data. Forest Science 53, 16.

Rawlings, J.O. 1988. Applied Regression Analysis : A Research Tool. Wadsworth \& Brooks/Cole Advanced Books \& Software. Pacific Grove, California.

Reynolds, M.R., T. E. Burk, and W. C. Huang. 1988. Goodness of fit tests and model selection procedures for diameter distribution model. Forest Science 34: 373-399.

Thomas, G. M., and B. S. Emily. 2008. Deriving Tree Diameter Growth and Probability of Survival Equations from Successive Diameter Distributions. Forest Science 54, 31.

Whitmore, T.C. and C.P. Burnham. 1984. Tropical Rain Forests of the Far East. second Edition. Oxford University Press. New York. 